\title{
TIME BUDGET PREASURE AND TURNOVER INTENTION WITH DYSFUCTIONAL ACCOUNTANT BEHAVIOR
}

\author{
1)JAMALUDDIN MAJID, ${ }^{2)}$ AMBO ASSE
}

${ }^{1)}$ Scholar of Doctoral, Department Accounting University of Hasanuddin Makassar, Indonesia

${ }^{2)}$ Department Accounting, State Islamic University of Alauddin Makassar, Indonesia Email :1)jamalmajid2018@gmail.com, ${ }^{2)}$ amboasse22uin@yahoo.co.id

\section{Paper ID : 5-2-4-20180222}

\begin{abstract}
A public accountant as a profession that provides assurance services about historical financial report information to the public is required to have adequate accounting knowledge and accounting skills as well as personal qualities. Such personal qualities will be reflected in his professional behavior. Professional behavior of public accountant one of them embodied in the form of avoid dysfunctional behavior of accountant. dysfunctional behavior is related to time budget pressure and turnoer intention. A high level of time budget pressure will encourage auditors to perform dysfunctional behaviors. The desire to quit working is also judged to affect the irregularities of auditor behavior. There is a significant positive correlation between intention turnover and dysfunctional audit behavior due to decreased fears of possible sanctions if such behavior is detected.
\end{abstract}

Keywords : Accountant, dysfucntional Behavior, time budget pressure and turnover intention.

\section{INTRODUCTION}

Public accounting profession is a profession based on the trust of the community that plays an important role in conducting an audit of an organization's financial statements. This profession is known to the public through the audit services provided to users of financial statements. Accountants are required to carry out their work professionally so that the work produced will be qualified. The quality of the auditor's work is related to the quality of the skills, the timeliness of the job completion and the independence of the company. According to Pujaningrum (2012) Society, especially the users of accountant services must feel confident and trust that the accountant in carrying out its duties has been based on good moral principles so that there is a guarantee that the public interest is protected from practices that are not true.

Every profession, especially those who provide services to the community, requires specialized knowledge and skills and each profession is expected to have a certain personal quality (Fatt, 1995 in Harini et al, 2010). A public accountant as a profession that provides assurance services about historical financial report information to the public is required to have adequate accounting knowledge and accounting skills as well as personal qualities. Such personal qualities will be reflected in his professional behavior. Professional behavior of public accountant one of them manifested in the form of avoid dysfunctional behavior of accountant (Pujaningrum, 2012). Dysfunctional behavior arises because of the

\section{DOI : 10.3828/IJEMSS/v1i1.2}

VOLUME 1 ISSUE 1 MARCH 2018

http://journals..salewangang.org/ojs/index.php/IJEMSS/index

Licensed Under Creative Commons Attribution 4.0 
e-ISSN 2614-3828 p-ISSN 2614-3887

cost-quality dilemma (McDaniel, 1990). Donnelly et al (2003) states that dysfunctional audit behavior is a reaction to the environment (such as control systems).

Dysfunctional behavior is defined as behavioral changes that may have an unpleasant effect on a Newstrom and Davis (1995) system. According to Soobaroyen (2006) the dysfunctional behavior is not just a human tendency that is "irrational" but rather leads to reactions that can be "rationally" suspected in responding to controls and processes Dysfunctional behavior is the actions when a subordinate manipulates the elements -a element of an existing control system for its own sake. The difference between functional behavior and dysfunctional behavior. Functional behaviors are able to work harder, impose the entire working time appropriately, and use more efficient checking techniques (Kelley and Seiler, 1982).

The theoretical basis used in this research is attribution theory. Theories of attribution that explain the process of how we determine the cause of one's behavior (Basudewa and Merkusiwati 2015). This theory refers to how one explains the cause of the behavior of another person or self determined by internal or external and its influence on individual behavior (Luthans, 2006, in Basudewa and Merkusiwati, 2015). We make an attribution when we describe a person's behavior and try to dig knowledge of why they behave that way. In his life, everyone is always shaping ideas about other people and the surrounding social situations through various things. In attribution theory Correspondent Inference, behavior associated with attitudes or personal characteristics, means by seeing behavior can be known with certain attitudes or characteristics of the person and the prediction of one's behavior in the face of certain situations.

Time pressure according to Solomon and Broen (2005) is a pressure on the audit time budget that has been prepared. Time pressure consists of two dimensions: time budget pressure and time deadline pressure. The emergence of time dealer pressure is caused by the need to complete audit tasks based on certain time guidelines. Auditors working in large firms under time budget pressure and engaging in dysfunctional behavior occur because the competition culture in the Public Accounting Firm big six is very tight (McNamara, 2008). Time budget pressure of an audit has a positive effect on dysfunctional behavior of auditors (Otley and Pierce, 1996). A high level of time budget pressure will encourage auditors to perform dysfunctional behaviors. Dysfunctional behavior of auditors will of course affect audit quality (Suprianto, 2009).

Turnover intention is related to employee's desire to switch work. According to Falikhatun (2014) turnover intention is the desire (consciousness or deliberate) auditors to leave the organization or looking for alternative jobs elsewhere. The willingness to exit the organization voluntarily can be functional and dysfunctional. The desire to exit from a functional organization, if an employee leaving the organization is an employee deemed worthy of exit (Basudewa dan Merkusiwati 2015). The desire to quit work is also judged to affect the deviation of auditors' behavior (Pujaningrum, 2012). Malone and Robert (1996) found evidence 
e-ISSN 2614-3828 p-ISSN 2614-3887

that there is a significant positive relationship between turnover intention and dysfunctional audit behavior because of a decrease in fear of a possible sanction if the behavior is detected. The literature suggests that dysfunctional audit behaviors occur in situations where individuals perceive themselves less able to achieve the expected outcomes or outcomes of their own enterprises (Gable and Dangello, 1994). However, in a study conducted Falikhatun (2009) found out that turnover intention does not affect the acceptance of dysfunctional behavior audit.

\section{MATERIAL AND METHOD}

The type of research is descriptive qualitative intended to obtain information about the relationship of time budget pressure, turnover intention with dysfunctional behavior in depth and comprehensive. In addition, with qualitative approach is expected to be disclosed situations and problems encountered in providing or receiving an accounting information.

This research is descriptive, with interview and documentation study. The data have been obtained will be analyzed qualitatively and described in the form of descriptive. Data analysis is the process of arranging the sequence of data, organizing it into a pattern, category and basic description. The definition provides an overview of how important the position of data analysis is viewed in terms of research objectives. The main principle of qualitative research is to find the theory of data.

\section{RESULT AND DISCUSSION}

Time budged pressure has a positive relationship with auditor dysfunctional behavior. Thus, it is known that a narrow time budget to audit can improve the dysfunctional behavior of the auditor in fulfilling the audit process that must be performed. The auditor determines the amount of time budget for various audit procedures based on the income received from the contract with the client. Most audit fees are triggered by audit timing, therefore, to improve the efficiency of one of the ways in which the Public Accounting Firm determines the time frame of the audit in conducting the audit. Accountants tend to lower the budgeted hours to increase their chances of improving their job evaluation to look better than their bosses (Nehme, 2017).

To receive a good performance assessment, by working and completing a profitable task, the auditor selected the highest threshold sampling technique that can help them to spend less hours in the field. Research of Hartanto's (2012) entitled "The Influence of Locus of Control, Budget Time Pressure of Professional Commitment, to Auditor Dysfunctional Behavior", shows the result that time budget pressure engages in dysfunctional behaviors, meaning that less budget time given to the auditor is higher for behavior dysfunctional. The population in the study is auditors at Public Accounting Firm in Surabaya. The target population is the auditor who works in the Public Accounting Firm in Surabaya. The auditor is chosen as a populace because the auditor goes straight to the field so it is more susceptible to dysfunctional behavior. The total number of auditors is 123 people. Sample criteria are 
auditors involved in the implementation of the audit program general (general audit) corporate reporting conducted Public Accounting Firm with audit experience for a minimum of 2 (two) years.

Turnover intention positively affects the deviant behavior in the audit (Chairunnisa et al, 2014). Auditors who have turnover intention or high work transfer desire can engage in deviant behavior in the audit because of the decrease in the level of fear that is in him against imposed sanctions if the behavior is detected. Auditor with good quality, but where the auditor works less then the auditor will think it will not take long to keep working in the accounting firm. Auditors will look for better accounting offices, and tend to perform dysfunctional behaviors. Auditors with good quality, but where the auditor works less well then the auditor will think it will not take long to keep working in the accounting firm. Auditors will look for better accounting offices, and tend to perform dysfunctional behaviors.

Basudewa and Merkusiwati (2015) aims to determine the influence of Locus Of Control, Organizational Commitment, Auditor Performance, and Turnover Intention on Deviant Behavior in Audit at Public Accounting Firm in Bali. The results of this study indicate that turnover intention has a positive and significant effect on deviant behavior in audit. The higher the intention turnover that an auditor has, the higher the deviant behavior is performed by an auditor. Auditors who have a desire to switch jobs are more likely to engage in dysfunctional behaviors, because of the decrease in fear of conditions that occur when they are detected. The population in this study are independent auditors working at Public Accounting Firm in Bali, using purposive sampling method, with judgment sampling technique. The data collection method used is questionnaire method (questionnaire) that is spread the questionnaire questionnaire that will be filled or answered by the auditor respondents at Public Accounting Firm in Bali. In the research using the scale of measurement (assessment) five Likert Scale The study was tested using multiple linear regression analysis with SPSS 15.00 for windows program.

The results of the review of some references show the result that the higher intention turnover owned by an auditor the higher the deviant behavior performed by an auditor. The results show Sitanggang (2007) proves that turnover intention has a positive effect on the behavior of deviant in the audit. Malone and Roberts (2003) found in Pujaningrum research (2012) explain that auditors who have the desire to switch jobs are more likely to engage in dysfunctional behavior, due to a decrease in fear of conditions that occur when it is detected. Turnover intention positively affects the deviant behavior in the audit. Auditors who have a turnover intention or high worktransfer desire may engage in aberrant behavior in the audit because of the decrease in the level of fear present within him against imposed sanctions if the behavior is detected. Individuals who intend to leave work are less concerned with the adverse effects of behavioral aberrations on performance appraisals and promotions.

The time limit is determined based on the previous audit time budget, so the auditor can estimate how long it will take to complete

\section{DOI : 10.3828/IJEMSS/v1i1.2}

VOLUME 1 ISSUE 1 MARCH 2018

http://journals..salewangang.org/ojs/index.php/IJEMSS/index

Licensed Under Creative Commons Attribution 4.0 
the audit program. Time budged is also determined by the client, when the client needs the audit report to be completed. The budget is also influenced by the fees paid by the client to the auditor, so that the auditor should be able to adjust the expenses that must be spent during the audit program runs to completion with the fee received. When an auditor is unable to complete an audit program within a prescribed time budget, the auditor is likely to engage in behavioral deviations such as dysfunctional behavior. Lucky (2012) states that TBP has a positive effect on dysfunctional behavior because of the unbalanced between task, time and cost received from clients.

Means the higher the time budged pressure level, the higher the auditor dysfunctional behavior. This is consistent with the research by Pierce et al (2004) which suggests budgetary pressures of audit time are positively associated with dysfunctional behavior of auditors. Thus, it is known that a narrow time budget to audit can improve the dysfunctional behavior of the auditor in fulfilling the audit process that must be performed. The auditor determines the amount of time budget for various audit procedures based on the income received from the contract with the client. Most audit fees are triggered by audit timing, therefore, to improve the efficiency of one of the ways in which the Public Accounting Firm determines the time frame of the audit in conducting the audit.

According to attribution theory, one's behavior is influenced by internal factors or external factors. In this study, attribution theory is used to explain the influence of individual accounting behavior (Time budget pressure) on the occurrence of dysfunctional behavior of audit. Time budget pressure is one of the external factors that influence the behavior of dysfunctional audit.

Having the desire to stop or move to work (turnover intention) can make a person less concerned about what is done in the organization where he works. This attitude can lead to poor performance for the employee so that it can lead to irregularities. Accountants who have a desire to get out of the organization where they take shelter tend to engage in Audit Dysfunctional Behavior. This is due to the decreasing fear of the consequences they will receive if the dysfunctional behavior is detected by their superiors. So they no longer feel worried or afraid in doing Dysfunctional Behavior Audit. There are three factors that influence employee's switching behavior cited by Fitriyani et al. (2010) that are external factors, work related factors, and personal factors. External factors include job opportunities, unemployment, union presence, and so on.

According to attribution theory, one's behavior is influenced by internal factors or external factors. In this study, attribution theory is used to explain the effect of personal characteristics of accountants (turnover intention) on which causes dysfunctional behavior. Turnover intention is one of the external and external factors, where the internal factors are job stress and external factors in terms of running the job. These internal and external factors can affect the occurrence of audit dysfunctional behavior.

The higher the auditor's intention turnover rate so that the deviant behavior in the audit will increase. Individuals who intend 
to leave work are less concerned with the adverse effects of behavioral aberrations on performance appraisals and promotions. Donelly, et.al (2003) found evidence that there was a significant positive correlation between turnover intention and deviant behavior in the audit because of a decreased fear of possible sanctions if such behavior was detected. This means that an auditor who has the desire to leave the company can be more involved in aberrant behavior in the audit caused by a decrease in the level of fear of imposing a sanction if such deviant behavior is detected.

Dysfunctional behavior occurs in situations when the individual feels he is less able to achieve the expected results through his own efforts. Individuals whose performance levels are below the expectations of supervisors have a greater likelihood of engaging in dysfunctional behavior because they consider themselves unable to survive in the organization through their own efforts. Thus, dysfunctional behavior is seen as necessary because individual or organizational goals can not be achieved through these levels of performance. Therefore, accountants with low perceptions of their performance are expected to show acceptance for higher dysfunctional behaviors.

From the results of this study obtained the results of the question about the formulation of this research problem is "What are the three characteristics, namely time budget pressure, turnover and dysfunctional behavior are interconnected". The results of this study indicate that the three variables are time budget pressure, turnover intention with dysfunctional behavior interconnected. Time budget pressure can cause an accountant to feel stressed in carrying out his profession that affects the desire to switch jobs. From the results of this study in turnover intention (desire to move work) have a positive relationship, the higher the desire to move places the higher the chance of dysfunctional behavior.

\section{CONCLUSION}

The auditor's belief that adhering to the time budget relates to performance appraisal will force the auditor to force himself to meet the time budget despite having to engage in dysfunctional behavior such as using an underreporting of time. The budged pressure timeline is a state in which the audit is required to consider the economic factor (time and costs) in determining the amount and competence of audit evidence collected. Thus, the auditor feels the pressure in completing the audit process due to unbalanced antitradies, time and cost received by the client. Because the pressure that management provides in determining the time budget is a critical factor in the auditor's behavior. The time budgeting experienced by the auditor can be stressful, and the stress will cause the auditor's desire to switch jobs.

The desire to move the auditor is a consequence of the auditor's dissatisfaction with the work he is doing right now. Job dissatisfaction can be caused by various factors such as work environment, salary, leadership and so forth. The dissatisfaction of the auditor to the work will cause feelings of dislike, upset even hate the accounting office where he works. These feelings will trigger the desire to move from the auditor. Turnover intention can be functional and dysfunctional. Desire out of a functional organization, if an employee leaving the organization is an

DOI : $10.3828 /$ IJEMSS/v1i1.2

VOLUME 1 ISSUE 1 MARCH 2018

http://journals..salewangang.org/ojs/index.php/IJEMSS/index

Licensed Under Creative Commons Attribution 4.0 
e-ISSN 2614-3828 p-ISSN 2614-3887

employee who is considered eligible to leave. This condition opens opportunities for highly motivated or capable people, opens opportunities for promotion, and opens new and fresh ideas for the organization. Desire comes out of dysfunctional organizations, if employees leaving the company are highability employees.

\section{REFFERENCE}

Alderman, C.W. and Deitrick, J.W., 1982. Auditors' perceptions of time budget pressures and premature sign-offs: a replication and extension, Auditing: $A$ Journal of Practice \& Theory, Winter: 54-68.

Aranya N, and K.R Ferris, 1984. A reexamination of accontant organizational professional conflict.The Acconting review. 59: 115

Basudewa, Dewa Gede Agung and Ni Kt. Lely Aryani Merkusiwati, 2015. The Influence of Locus Of Control, Organizational Commitment, Auditor Performance, And Turnover Intention On Deviant Behavior In Audit. EJournal of Accounting Udayana University, 13 (3): 944-972

Cook, E. and Kelley, T.,1988. Auditor stress and time budgets, The CPA Journal, July: 83-96.

Donnely, David P., Jeffrey J. Q, and David O., 2003 "Auditor Acceptance of Dysfunctional Audit Behavior : An Explanatory Model Using Auditors' Personal Characteristics." Journal of Behavioral Research In Accounting: vol $15: 87-107$
Eka Baskara, Agusta. Ardiani Ika S. 2010. "Auditor's Acceptance of Dysfunctional Audit Behavior (Empirical Study of Public Accountant Office in Central Java)". University of Semarang, Central Java.

Falikhatun. 2009. Effect of Turnover Intention, Self Rate Employee Performance, And Self Estem To Receiving Dysfunctional Behavior In Audit In Gender Perspective (Study At Public Accounting Firm In Central Java). Media Research Accounting, Auditing, \& Information, 9 (3): 1-16

Fitriyani., Gani, L., S, Sylvia V. N. P., Marganingsih, A., and Anggrahita, V. 2010. Analysis of Factors Affecting Job Satisfaction Auditor And Its Relationship With Performance And Desire Working Auditor. National Symposium of Accounting, Purwokerto.

Gable, M., dan F. Dangello. 1994. Locus of Control, Machiavellianisme, and Managerial Job Performance. The Journal of Psichology, 599-608.

Harini, Dwi, Wahyudin A, Anisyakurillah I, 2010, Auditor's Acceptance Analysis of Dysfunctional Audit Behavior: A Characteristic Approach Personal Auditor, SNA XIII, Purwokerto.

Herningsih, Sucahyo. 2001. Premature Termination of Audit Procedures: Empirical Study at Public Accounting Firm. Thesis, University of Gajah Mada Yogyakarta.

Kelley, T. \& Seiler, R. E. 1982. Auditor Stress and Time Budgets." The CPA Journal, December, pp. 24-34. 
e-ISSN 2614-3828 p-ISSN 2614-3887

Malone.C.F \& Roberts,R.W. 1996. Factors Associated with the incidence of reduced audit quality behavior. Auditing, 15 Managerial Job Performance. The Journal of Psichology. pp.599-608.

McDaniel, L. S. 1990. The Effects of Time Pressure and Audit Program Structure on Audit Performance. Journal of Accounting Research. Vol. 28, no. 2. pp 267-285.

McNair, C. J., 1991. Proper compromises: The management control dilemma in public accounting and its impact on auditor behaviour. Accounting, Organizations and Society, 16(7), 635-653.

McNamara, S.M, Liyanarachchi, 2008. Time budget Pressure and auditor dysfungsional behaviour within an occupation stress model. Accountancy Business and the public Interest, 7(1)

Newstrom, John W \& Davis, Keith. 2002. Organizational behaviour: Human Behavior at Work. 11th Edition. The McGraw - Hill/Irwin, New York

Otley, David T., dan Bernard J. Pierce. 1996. "Auditor Time Budget Pressure: Consequences and Antecedents." Accounting, Auditing \& Accountability Journal 9, no. 1: 31-58.

Paino, Halil, Ismail, Zubaidah dan Smith Malcolm. 2012. Modelling Dysfunctional Behaviour: Individual Factors and Ethical Financial
Decision. Social and Behavioral Sciences 145: 116-128.

Pujaningrum, Intan and Arifin Sabeni. 2012. Analysis of Factors Affecting the Level of Auditor's Acceptance of Behavior in Auditing Behavior. Diponegoro Journal of Accounting, 1 (1): 1-15.

Robbins, Stephen P and Timothy A Judge. 2014. Organizational Behavior. Jakarta: Salemba Empat.

Salomon, I. Dan Brown, C. 2005. Auditor Judgetment Under Time Pressure: An Agenda For Research And An Ilustrasion. Auditing Symposium XI. University of Kansas Symposium on Auditing Problem, 73-91

Shapeero, Mike, Hian Chye Koh dan Larry N. Killough. 2003. "Underreporting and Premature Sign-Off in Public Accounting", Managerial Auditing Journal, hal. 478-489.

Silaban, A. 2011. Influence Multidimensional Professional Commitment to Dysfunctional Auditing Behavior. Journal of Accounting \& Auditin ,. 8 (1): 1-94.

Soobaroyen, T. 2006. Management control systems and dysfungsional behavior an empirical investigation, Management Accounting Section Meeting Conference Reviewers.

Suprianto, Edy. 2009. Effect of Time Budget Pressure on Auditor Dysfunctional Behavior. JAI, 5 (1): 57-65 